\title{
Composition and oil characteristics of apricot, peach and cherry kernel
}

\author{
By Evangelos S. Lazos \\ Department of Food Technology - School of Food Technology and Nutrition \\ TEl of Athens \\ Saint Spyridon Str., Egaleo - Athens 122 10, Greece
}

\section{RESUMEN}

\begin{abstract}
Composición y características de aceite de hueso de albaricoque, melocotón y cereza.

Se han obtenido huesos de albaricoque, melocotón y cereza de vegetales procesados y se han separado y analizado las pepitas después de eliminar las cáscaras. El aceite crudo, extraído con éter de petróleo, fue $38^{\prime} 4,48^{\prime} 0$ y $26^{\prime} 0 \%$ de materia seca de pepitas de albaricoque, melocotón y cereza respectivamente; el contenido en proteina cruda fue $21^{\prime} 2,26^{\prime} 7$ y $25^{\prime} 3 \%$; fibra bruta $5^{\prime} 0,5^{\prime} 4$ y $9^{\prime} 5 \%$; hidratos de carbono totales $32^{\prime} 4,16^{\prime} 0$ y $34^{\prime} 5 \%$ de los cuales $9^{\prime} 3,7^{\prime} 1$ y 11 ' $3 \%$ fueron azúcares reductores; y ceniza $3^{\prime} 0,4^{\prime} 0$ y $4^{\prime} 6 \%$ respectivamente. Se han encontrado en las pepitas cantidades considerables de $\mathrm{K}, \mathrm{P}, \mathrm{Mg}$ y $\mathrm{Ca}$; se han tabulado valores para 15 minerales. Las características del aceite fueron: indice de iodo 105, 97, 116 indice de saponificación 195, 201, 198; materia insaponificable 0'95, $1^{\prime} 60,33^{\prime} 12 \%$; indice de refracción $\left(40^{\circ} \mathrm{C}\right) 1^{\prime} 4635,11^{\prime} 4622,1^{\prime} 4693$; gravedad especifica $\left(20^{\circ} \mathrm{C}\right) 0^{\prime} 9227,0^{\prime} 9158,0^{\prime} 9419$ para aceite de pepita de albaricoque, melocotón y cereza respectivamente. El ácido graso dominante fue el oléico $\left(68^{\prime} 0,69^{\prime} 0,46^{\prime} 0 \%\right.$ respectivamente) seguido por el linoleico $\left(24^{\prime} 2,22^{\prime} 0,41^{\prime} 6 \%\right.$ respectivamente). Se han encontrado también en concentraciones traza C12:0, C14:0, C14:1 C15:0, C15:1, C16:0, C16:1, C17:0, C17:1, C18:0, C18:3, C20:0 y C20:1. El esterol principal fue el $B$-sitosterol alcanzando alrededor del $90 \%$, seguido por el campesterol. Se han encontrado asimismo colesterol, estigmasterol, $\Delta^{5}$ - avenasterol, $\Delta^{7}$ - estigmasterol y $\Delta^{7}$ avenasterol.
\end{abstract}

PALABRAS-CLAVE: Acido graso (composición) - Esterol (composición) -Mineral (contenido) - Pepita de albaricoque (aceite) - Pepita de cereza (aceite) - Pepita de melocotón (aceite).

\section{SUMMARY}

Composition and oil characteristics of apricot, peach and cherry kernel.

Apricot, peach and cherry pits were obtained from processing plants and after removal of hard shells the kernels were separated and analyzed, and crude oil was extracted with petroleum ether. Crude oil was $38.4,48.0$ and $26.0 \%$ of dry matter of apricot, peach and cherry kernels respectively; crude protein content was 21.2, 26.7 and 25.3\%; crude fibre 5.0, 5.4 and $9.5 \%$; total carbohydrates $32.4,16.0$ and $34.5 \%$ of which $9.3,7.1$ and $11.3 \%$ were reducing sugars; and ash $3.0,4.0$ and $4.6 \%$ respectively. The kernels were found to contain considerable amounts of $\mathrm{K}, \mathrm{P}, \mathrm{Mg}$ and $\mathrm{Ca}$; values for 15 minerals are tabulated. Oil characteristics were: iodine value 105, 97, 116; saponification number 195, 201, 198; unsaponifiable matter $0.95,1.60$, $3.12 \%$; refractive index $\left(40^{\circ} \mathrm{C}\right) 1.4635,1.4622,1.4693$; and specific gravity $\left(20^{\circ} \mathrm{C}\right) 0.9227,0.9158,0.9419$ for apricot, peach and cherry kernel oil respectively. The dominant fatty acid was oleic $(68.0,69.0$, $46.0 \%$ resp.) followed by linoleic $(24.2,22.0,41.6 \%$ resp.). In lower concentrations to traces $C_{12: 0} C_{14: 0}, C_{14: 1}, C_{15: 0}, C_{15: 1}, C_{16}: 0$
C16:1, C17:0, C17:1, C18:0, C18:3, C20:0, and C20:1 were also found The main sterol was B-sitosterol amounting over $90 \%$ and followed by campesterol. Cholesterol, stigmasterol, $\Delta^{5}$-avenasterol, $\Delta^{7}$-stigmasterol and $\Delta^{7}$-avenasterol were also found.

KEY-WORDS: Apricot kernel (oil) - Cherry kernel (oil) - Fatty acid (composition) - Mineral (content) - Peach kernel (oil) - Sterol (composition).

\section{INTRODUCTION}

A serious problem faced by the food industry is the accumulation, handling and disposal of proccesing wastes, and there is an increasing demand for their convertion into useful by-products. Obviously, such utilisation of food proccesing wastes could provide extra income and at the same time help minimize a waste disposal problem. It sould be pointed out that such utilization could be done economically only in locations where such wastes are available in large quantities.

The commercial processing of some Rosaceae such as peach (Prunus persica), apricot (Prunus armeniaca) and cherry (Prunus avium and $P$. cerasus) is of great importance in Greece. The annual production of peaches averages about 600,000 metric tons, of apricots 120,000 and that of cherries about 31,000 metric tons. Approximately $47 \%$ of the produced amounts is processed for canned product, juice, pulp and marmelade production. During processing, large amounts of pits are produced and accumulated, which may be utilized as a source of nutrients.

Apricot, peach and cherry kernels have been utilized for oil and macaroon paste manufacture (1). They also have been evaluated by several workers (2) (3) (4) (5) (6) (7) (8) (9) (10) (11) (12) for various specific uses, processing, organoleptic and chemical properties and found to contain $10.8-57 \%$ crude oil, $23-30 \%$ crude protein, $15-19 \%$ carbohydrates and $2.5-3 \%$ ash. Their oils have a high percentage of unsaturated fatty acids with oleic $(31-80 \%)$ and linoleic $(6.3-51 \%)$ being the dominants (3) (5) (13) (14) (15) (16) (17) (18) (19) (20) (21). According to FAO pattern apricot and peach kernel protein was found to contain 
suitable amounts of methionine, phenylalanine, valine, threonine and tryptophane (4) (7) (8). Ekpenyong (4) has reported that apricot, peach and cherry kernel protein contained a high percentage of glutamic acid followed by arginine and aspartic acid, while the least represented amino acid in all cases was methionine.

Depending on cultivar, apricot, peach and cherry kernels have a bitter taste and the bitternes is due to the presence of amygdaline. Although accidental cyanide poisoning from consumption of such kernels are not frequently reported, always there is a need for amygdaline removal before use in food products.

The aim of this study was to investigate the composition of Greek apricot, peach and cherry kernels from pits produced during industrial processing.

\section{MATERIALS AND METHODS}

Samples of apricot, peach and cherry pits were obtained from processing plants of Central Macedonia (Greece), sundried and kept for further preparation and analysis. After shell removal, the kernels were cut in a blender and ground in a Brabender mill to pass through a $1.00 \mathrm{~mm}$ sieve.
Kernel oil was extracted with petroleum ether (boiling point $30-60^{\circ} \mathrm{C}, 24 \mathrm{~h}$ ) in a Soxhlet extractor, the solvent was removed under reduced pressure and the oil stored in sealed glass bottles at $0-4^{\circ} \mathrm{C}$.

Moisture, crude oil, crude protein ( $N \times 6.25)$, crude fibre and ash were analysed using AOAC (22) procedures. Reducing sugars were extracted by the method of Hymowitz et al (23) and quantitatively determined by the colorimetric method of Dubois et al (24).

Minerals (Al, $\mathrm{Ca}, \mathrm{Co}, \mathrm{Cr}, \mathrm{Cu}, \mathrm{Fe}, \mathrm{K}, \mathrm{Li}, \mathrm{Mg}, \mathrm{Mn}$, $\mathrm{Mo}, \mathrm{Na}, \mathrm{Ni}$ and $\mathrm{Zn}$ ) were determined by atomic absorption spectroscopy, using a Perkin-Elmer 2380 instrument and phosphorus by the spectrophotometric molybdovanadate method (22) after dry ashing.

Oils were analysed in triplicate for acidity, iodine value, saponification number and unsaponifiable matter by AOAC (22) methods. Refractive index was determined by an Abbe refractometer with temperature adjustment. Specific gravity was determined by a pycnometer at $20^{\circ} \mathrm{C}$. The unsaponifiable matter of the oils was separated using thin layer chromatography (TLC) (silica gel, $20 \times 20 \mathrm{~cm}$ plates), developed in ethyl ether: petroleum ether (1:1). Identification was made by comparison of Rf values with standards.

Table 1

Approximate composition and mineral content of apricot, peach and cherry kernels (dry basis).

\begin{tabular}{lrrr}
\hline Assay & P.pricot & Peach & Cherry \\
\hline Crude oil (\%) & 38.4 & 48.0 & 26.0 \\
Crude protein (Nx6.25) (\%) & 21.2 & 26.7 & 25.3 \\
Crude fibre, (\%) & 5.0 & 5.4 & 9.5 \\
Ash, (\%) & 3.0 & 4.0 & 4.7 \\
Total carbohydrates & 32.4 & 16.0 & 34.5 \\
Reducing sugars, (\%) & 9.3 & 7.1 & 11.3 \\
Minerals (mg/100g) & & & \\
Al & 1.0 & 1.0 & 7.4 \\
Ca & 19.2 & 17.3 & 24.2 \\
Co & $*$ & $*$ & $*$ \\
Cr & 0.2 & 0.2 & $*$ \\
Cu & 1.3 & 1.0 & 1.1 \\
Fe & 1.3 & 1.4 & 2.7 \\
K & 685.0 & 691.0 & 906.0 \\
Li & 2.4 & 2.0 & 3.3 \\
Mg & 156.0 & 102.0 & 66.8 \\
Mn & 2.0 & 2.9 & 2.3 \\
Mo & $*$ & $*$ & $*$ \\
Na & 7.0 & 16.0 & 14.0 \\
Ni & 0.2 & 0.2 & $*$ \\
P & 519.0 & 565.0 & 608.0 \\
Zn & 1.5 & 0.9 & 1.3 \\
\hline
\end{tabular}

* Below detection limit of the assay 
Fatty acid composition was determined as methyl esters by gas-liquid chromatography (GC) using a Hewlett Packard 5840A instrument. Methyl esters were prepared by treating with methanolic $\mathrm{NaOH}$ and $\mathrm{BF}_{3}-\mathrm{MeOH}$ according to the method of Metcalfe et al (25). Chromatographic conditions were: helium carrier, $0.4 \times 244 \mathrm{~cm}$ stainless steel column, 20\% DEGS on Chromosorb W-AW 80/100 mesh, $185^{\circ} \mathrm{C}$, injector $210^{\circ} \mathrm{C}$, flame ionization detector $300^{\circ} \mathrm{C}$. Compounds were identified and quantified by peak retention times and area of the unknowns with those of fatty acid methyl ester standards (Supelco, Inc).

For sterol analysis, the TLC plates, prepared as described above, sprayed with dichlorofluorescein and the sterol bands were separated, extracted with ethyl ether, and the solvent evaporated under reduced pressure. Methyl acetate was added and the sterols were analyzed by GC as follows: $0.4 \times 185 \mathrm{~cm} \mathrm{OV-17}$ glass column, $265^{\circ} \mathrm{C}$, injector $280^{\circ} \mathrm{C}$, detector $300^{\circ} \mathrm{C}$, carrier gas helium. Cholesterol, campesterol, stigmasterol and B-sitosterol were used as standards.

\section{RESULTS AND DISCUSSION}

Table I shows the proximal composition of apricot, peach and cherry kernels. Moisture content was 9.7,
7.4 and $7.8 \%$ respectively for the three species. Peach kernel was found to have the highest crude oil content and cherry kernel the lowest. Oil content in apricot kernel was lower than that reported by Lotti et al (16) and Salem and Abu Salem (7), while that of peach kernel was in the higher end of the reported range by various workers (5) (8) (14) (18). Cherry kernel oil content was within the reported range of $10.8-31.6 \%$ (15) (26).

Crude protein and fibre content of all three kernels was in line with the values reported in literature (4) (8). Cherry kernels showed a relatively high crude fibre content, which could be attributed to the presence of a notable amount of not normally grown kernels.

Reducing sugar levels were higher than the previous reports (7) (8) (17) (27). Apricot, peach and cherry kernels are also good sources of minerals, especially $\mathrm{K}, \mathrm{P}, \mathrm{Mg}$ and $\mathrm{Ca}$, although the values for apricot kernel also differ from the results of Normakhatov and Khudaishukurov (6) and Gabrial et al (11). These differences may be caused by variation in cultivar or origin.

Oil characteristics are shown in Table II. The oil of all three kernels was a yellowish-brown liquid at

Table II

Characteristics and fatty acid composition of crude apricot, peach and cherry kernel oil.

\begin{tabular}{lccc}
\hline Assay & Apricot & Peach & Cherry \\
\hline Oil characteristics & & & \\
Acidity (\% as oleic) & 0.9 & 2.1 & 1.4 \\
Iodine value (Wijs) & 105.0 & 97.0 & 116.0 \\
Saponification number & 195.0 & 201.0 & 198.0 \\
Unsaponifiable matter (\%) & 0.95 & 1.60 & 3.12 \\
Refractive index (400C) & 1.4635 & 1.4622 & 1.4693 \\
Specific gravity (20\%C) & 0.9227 & 0.9158 & 0.9419 \\
Fatty acids (\%) & & & \\
$12: 0$ & tr & tr & 0.04 \\
$14: 0$ & 0.12 & 0.13 & 0.08 \\
$14: 1$ & 0.01 & 0.02 & tr \\
$15: 0$ & $\operatorname{tr}$ & 0.05 & 0.05 \\
$15: 1$ & $\operatorname{tr}$ & 0.03 & - \\
$16: 0$ & 4.93 & 6.27 & 8.60 \\
$16: 1$ & 0.88 & 0.42 & 0.44 \\
$17: 0$ & 0.08 & 0.04 & tr \\
$17: 1$ & 0.10 & 0.11 & 0.02 \\
$18: 0$ & 1.26 & 1.65 & 2.86 \\
$18: 1$ & 68.00 & 69.00 & 46.00 \\
$18: 2$ & 24.20 & 22.02 & 41.59 \\
$18: 3$ & 0.01 & 0.05 & 0.08 \\
$20: 0$ & 0.08 & 0.10 & tr \\
$20: 1$ & 0.11 & 0.08 & - \\
\hline
\end{tabular}

$\operatorname{tr}=$ trace 
Table III

Sterol composition of unsaponifiable matter of crude apricot, peach and cherry kernel oil.

\begin{tabular}{lccc}
\hline \multicolumn{1}{c}{ Sterol } & Apricot & Peach & Cherry \\
\hline Cholesterol & 0.24 & 0.16 & 0.22 \\
Campesterol & 3.39 & 3.57 & 1.28 \\
Stigmasterol & 1.97 & 0.13 & 0.10 \\
B-Sitosterol & 92.40 & 94.27 & 97.28 \\
$\Delta^{5}$-avenasterol & 1.35 & 0.43 & 0.85 \\
$\Delta^{7}$-stigmasterol & 0.10 & 0.64 & - \\
$\Delta^{7}$-avenasterol & 0.45 & 0.36 & tr \\
\hline
\end{tabular}

ambient temperature with high iodine and saponification numbers characteristic of many seed oils. The iodine value and saponification number were in the reported range of $89-159$ and $188-200$, repectively (3) (13) (14) (15) (16) (18) (21) (26) (28) (29). Specific gravity at $20^{\circ} \mathrm{C}$ was $0.9227,0.9158$ and 0.9419 and refractive index at $40^{\circ} \mathrm{C} 1.4635,1.4622$ and 1.4693 respectively for apricot, peach and cherry kernel oil and fell in the reported range (3) (13) (14) (15) (16) (20) (26) (29).

Regarding fatty acid composition, the saturates composed an average of 6.47 (apricot), 8.24 (peach) and $11.63 \%$ (cherry) of the total fatty acids. The major saturated fatty acid was palmitic (16:0) consisting ca. $76 \%$ of the total saturates. In lower concentrations to traces were also found myristic (14:0), pentadecanoic $(15: 0)$, heptadecanoic $(17: 0)$, stearic $(18: 0)$ and arachidic $(20: 0)$ acid. The major unsaturated fatty acid in the three oils was oleic $(18: 1)$, followed by linoleic (18:2). Minor to trace amounts of myristoleic (14:1), pentadecenoic (15:1), palmitoleic (16:1), heptadecenoic (17:1), linolenic (18:3) and eicosenoic (20:1) acid were also found. The composition of oils confirms that found by various workers (3) (5) (13) (14) (15) (16) (17) (18) (19) (20) (21) (26) (30) (31) (32). Differences were found in fatty acids contained in minor amounts. It should be noted that apricot, peach and cherry kernel oils resemble each other in fatty acid composition, with cherry kernel oil having a higher linoleic acid content. The observed differences were of no practical value owing to the great differences between cultivars.

The TLC analysis of the unsaponifiable matter of the oils showed the probable presence of sterols, alcohols, tocopherols $(\alpha-, \beta-\gamma-)$ and hydrocarbons both saturated and unsaturated.

Sterol composition of unsaponifiable matter are shown in Table III.

The main sterol of the unsaponifiable matter of the apricot, peach and cherry kernel oil was B-sitosterol amounting more than $90 \%$ of the total sterols and followed by campesterol (1.28 - 3.57\%). Amounts more than $1 \%$ were also found for stigmasterol and $\Delta^{5}$-avenasterol in apricot kernel oil unsaponifiables. Low to trace amounts of cholesterol, $\Delta^{7}$-stigmasterol and $\Delta^{7}$-avenasterol were also found. These results were in good agreement with those reported by Awad (33), Zürcher and Hadorn (17), Lotti et al (18), Salvo et al (32) and Ogihara et al (19), although higher percentages for campesterol, $\Delta^{5}$-avenasterol and a trace of brassicasterol in peach and apricot unsaponifiable have been reported by Lotti et al (18) and Salvo et al (32). El-Tahawi et al (29) have also reported that TLC of peach oil extracted with $n$-hexane gave $3.39 \%$ cholesterol and $45 \%$ B-sitosterol.

On the basis of the above results apricot, peach and cherry kernels are rich in nutrients and could be utilized succesfully as a source of protein, especially the detoxified apricot and peach kernels, flour and protein isolates in bakery and confectionary products. Kernel oil could be utilized for cooking and in cosmetic products replacing the more expensive almond oil, as peach and apricot kernel oil resembles almond oil. Pit shells could also be utilized for the production of various products such as dietary fibres and char. It is obvious that these wastes are a source of goods and upon utilization could provide extra income.

\section{REFERENCES}

1. Cruess, W. V.-"Commercial Fruit and Vegetable Products".McGraw Hill Publishing Co., 1958.

2. Anon.-"Kerne and Fruechte in der Suesswarenindustrie".-Int. Rev. Sugar Confection 25 (1972) 415-417.

3. Gad, A. M.; El-Khalafy, H. M.; Hassan, M. M., and Soeb, Z. E.-"Chemical investigations on Egyptian vegetable fats and oils. XIII. The chemical constitution of some Rosaceae, Solanaceae and Oleaceae seed oils.-Grasas y Aceites 19 (1968) 139-145.

4. Ekpenyong, T.-"Amino acid content of seeds of orchard crops".-J. Sci. Food Agric. 20 (1969) 608-610.

5. Neubeller, J., and Buchloh, G.-"Untersuchungen über Fettbildung und Fettsäuremuster in Samen verschiedener Obstarten".-Mitt. Rebe, Wein, Obstbau Fruechteverwertung 20 (1970) 305-313.

6. Normakhatov, R., and Khudaishukurov, T.-"Apricot stone kernels as a valuable commercial by-product".-Konserv. Ovoshch. Promyshl. (10) (1973) 32-33

7. Salem, S. A., and Abu Salem, F. M.-“Egyptian apricot kernels seeds".-Disch. Lebensmittel-Rdsch. 69 (1973) 322-324. 
8. Salem, S. A., and Abu Salem, F. M.-"Egyptian peach kernel seeds".-Dtsch. Lebensmittel-Rdsch. 70 (1974) 359-360.

9. Hallabo, S. A. S.; El-Wakeil, F. A., and Morsi, M. K. S.-“Chemical and physical properties of apricot kernel, apricot kernel oil and almond kernel oil".-Egyptian J. Food Sci. 3 (1975) 1-6.

10. Bhatia, A. K.-"Apricots of Ladakh: status and problems".-Indian Food Packer 30 (1976) 35-37.

11. Gabrial, G. N.; El-Nahry, F. I.; Awadalla, M. Z., and Girgis, S. M.-"Unconventional protein sources: apricot seed kernels".Zeitschrift fur Ernaehrungswinssenschaft 20 (1981) 208-215.

12. Abd-El-Aal, M. H., and Hamza, M. A.-"In vitro digestibility, physicochemical and functional properties of apricot kernel proteins".-Food Chem. 19 (1986) 197-211.

13. Gupta, D. R., and Garg, S. K.-"Chemical examination of the seed fat of Prunus persica Batsch".-Fette, Seifen, Anstrichmittel 70 (1968) 488.

14. Lotti, G., and Anelli, G.-"Gli oli di semi di Prunus persica Sieb".-Riv. Ital. Sostanze Grasse 46 (1969) 110-114.

15. Lotti, G.; Pisano, G., and Baragli, S.-"Caratterizzazione degli oli di semi albicocche".-Riv. Ital. Sostanze Grasse 47 (1970) 867 871.

16. Lotti, G.; Pisano, G.; Anelli, G., and Baragli, S.-"Gli oli di semi di una serie di cultivar di ciliege".-Scienza Alimentazione 16 (1970) 248-253

17. Zürcher, K., and Hadorn, H.-"Neuere Methoden zur Untersuchung von Mandeln, Aprikosenkernen, Haselnüssen und Erdnüssen".Mitt. Gebiete Lebensm. Hyg. 67 (1976) 170-191.

18. Lotti, G.; Izzo, R., and Bottazzi, F.-"Il composizione lipidica di semi oleosi durante la maturazione e la post-maturazione".-Riv. Soc. It. Sci. Alim. 9 (1980) 405-414.

19. Ogihara, $\mathrm{H}_{\text {; }}$ : Itoh, S., and Tsuyuki, H.-"Studies on the lipids in seed of ume apricot".-Bull. Coll. Agr. Vet. Med., Nihon Univ. 39 (1982) 97-106.

20. Takenaga, F.; Itoh, S., and Tsuyuki, H.-"Chemical properties of total lipids and neutral lipids in seeds and endocarps of peaches".-Nippon Shokuhin Kogyo Gakkaishi 29 (1982) 724-729.

21. Farines, M.; Soulier, J., and Comes, F.-"Study of the glyceride fraction of the kernel oils from some Rosaccae".-Rev. Fr. Corps Gras 33 (1986) 115-117.
22. AOAC.-"Official Methods of Analysis, 12th Ed.".-Association of Official Analytical Chemists, Washington, D. C., 1975.

23. Hymowitz, T.; Collins, F. I.; Pauczner, J., and Walker, W. M.-"Relationship between the content of oil, protein and sugar in soyabean seed".-Agronomy J. 64 (1972) 613-616.

24. Dubois, M. Gilles, K. A. Hamilton, J. K.; Reberts, P. A., and Smith, F.-"Colorimetric method for determination of sugars and related substances".-Anal. Chem. 28 (1956) 350-356.

25. Metcalfe, L. D.; Schmitz, A. A., and Pelka, J. R.-“Rapid preparation of fatty acid esters from lipids for gas chromatographic analysis".-Anal. Chem. 38 (1966) 514-515.

26. Farrohi, F., and Mehran, M.-"Oil characteristics of sweet and sour cherry kernels". J. Am. Oil Chemists' Soc. 52 (1975) 520-521.

27. Nickel, S. L., and Maruyama, T.-“Sugar content of commercially processed peach pit kernels and shells".-Dtsch. LebensmittelRdsch. 79 (1983) 19-20.

28. Filsoof, M.; Mehran, M., and Farrohi, F.-"Determination and comparison of oil characteristics in Iranian almond, apricot and peach nuts".-Fette, Seifen, Anstrichmittel 78 (1976) 150-151.

29. El-Tahawi, B. S.; Diab, M. A.; Habib, M. A., and Aly, M. A.-"Steroid composition of the Egyptian peach oil".-Minufiya J. Agric. Res. 6 (1983) 303-319.

30. Carpenter, D. L.; Lehmann, J.; Mason, B. S., and Slover, H. T.-"Lipid composition of selected vegetable oils".-J. Am. Oi Chemists' Soc. 53 (1976) 713-718.

31. Haggag, M. Y., and Hifnaway, M. S.-"Study of lipid of Prunus armeniaca L. seeds".-Bull. Fac. Pharm., Cairo Univ. 13 (1974) 175-181.

32. Salvo, F.; Dugo, G.; D'Alcontres, I. S.; Cotroneo, A., and Dugo, G.-"Composizione dell'olio di mandrole. Nota II: differenziazione dell'olio di mandorle dolci da sue miscele con olio di semi di pesco e di albicocco".-Riv. Ital. Sostanze Grasse 57 (1980) 2426.

33. Awad, O.-"Steroidal estrogens of Prunus armeniaca seeds".-Phytochemistry 13 (1974) 678-679.

(Recibido: Julio 1991) 